DOI: https://doi.org/10.24144/2409-6857.2018.1(51).230-235

УДК 635.52:005.412 - 047.44:004.925.8

\author{
Магденко C.O.
}

\title{
МОДЕЛЮВАННЯ КОМПЛЕКСНОЇ ОЦІКИ РОЗВИТКУ ПІДПРИЄМСТВ М'ЯСОПЕРЕРОБНОЇ ГАЛУЗІ
}

\begin{abstract}
В статті розглядаються питання моделювання комплексної очінки розвитку підприємства як вертикально інтегрованої системи, яка включає три блоки: блок постачання, блок безпосередньо виробництва $i$ блок реалізації готової продукиії. Для кожного блоку розраховуються часткові показники, темпи їх зростання, розраховані ланцңюговим способом. Кожен блок характеризується середньогеометричною величиною. Модель комплексної оцінки представляється як середньо геометрична з добутку середньогеометричних значень кожного блоку. На підставі отриманого результату можна характеризувати напрям і рівень розвитку підприємства, а також проаналізувати зміни значень показників, які вплинули на кінцевий результат і прийняти відповідні управлінські рішення до подальшої стратегї розвитку підприємства.
\end{abstract}

Ключеві слова: підприємство, розвиток підприємства, комплексна оцінка, темпи зростання, моделювання

Постановка проблеми. Питання розвитку підприємств м'ясопереробної галузі у сучасних умовах являється однією із складових реалізації продовольчої програми забезпечення населення країни раціональним споживанням.

На розвиток підприємств м'ясопереробної галузі впливають низка факторів:

по-перше, обмеженість вітчизняної сировини, особливо м'яса ВРX, що потребує використовувати імпортоване м'ясо;

по-друге, великій знос основних засобів на більшості підприємств, оновлення яких потребує додаткових коштів, яких у більшості підприємств немає;

по-третє, обмеженість купівельної спроможності населення, що привело до зміни структури споживання, переходу на більш низький ціновий рівень.

Тому подальший розвиток підприємств потребує комплексного рішення проблеми, об'єднавши в систему розвитку тваринництва, переробки м'яса i реалізації продукції споживачам i, на цієї основі розробити модель комплексної оцінки результатів розвитку даної системи. Реалізація такого підходу рішення проблеми потребує державної підтримки, доступних кредитів i стимулюючого оподаткування.

Аналіз останніх досліджень i публікацій. Питання росту, розвитку i ефективного функціонування підприємства достатньо багато розглянуто в працях іноземних i вітчизняних

(C) Магденко Світлана Олександрівна, ст.викладач кафедри економіки промисловості, Одеська національна академія харчових технологій, м.Одеса, тел.: 0937515149, email: maglana1@ meta.ua вчених. Сучасними дослідниками можна вважати Бойко В.I., Богомазова В., Богатирьова I.O., Василенко В.О., Грачева М.В., Забродську Л.Д., Захорук О.В., Масленнікова Н.А., Раєвську О.В., Рябоконь В.П. Саблук П.Т, Штимер Л.Т. та інш., в роботах яких також розглядались окремі питання розвитку підприємств м'ясопереробної галузі. Разом з тим, розвиток не може бути без визначення стратегії зростання підприємства. Питання стратегій розвитку досліджували I. Ансофф, І.О.Бланк, П. Друкер, Г.Мінцберг, М. Портер, В.В. Пастухов, З.Є Шереметьєва, О.Ю. Церекаєва та ін. Питання модулювання оцінки розвитку підприємств за окремими напрямками досліджувалось в роботах Бондарчук О.М., Гончарука А.Г., Кравчук І.С., Осипова П.В., Ощепкова О.П., Тищенко О.М., Янкового А.Г. та ін., в т.ч. й автора.

Однак, питання розвитку i зростання підприємств, як правило, розглядались не системно, а лише за окремими напрямками розвитку окремих елементів системи: основних засобів, конкурентоспроможності, ефективності праці, інноваційного розвитку, але моделювання комплексної оцінки розвитку діяльності підприємств не досліджувалось.

Формування цілей статті. На підставі характеристики підприємства як системи розробити систему критеріїв і показників, на базі яких буде розроблена модель комплексної оцінки рівня розвитку певного підприємства. На підставі статистичних даних про діяльність підприємства м'ясопереробної галузі України надати результати модульної комплексної оцінки рівня його розвитку як вертикально інтегрованої системи.

Опис основного матеріалу дослідження. 
Підприємство як систему характеризує те, що всі елементи його структури між собою взаємозв'язані. Тому зміни в будь-якому із елементів обов'язково потребує змін в інших його елементах. Будь-яка система потребує наявності елементів, структури, організації та взаємозв'язку між елементами структури. Тобто, підприємству будь-якої галузі притаманні наступні елементи: робоча сила, основні засоби, оборотні кошти, відповідні технології та організація виробництва і праці, як форми взаємозв'язку між елементами структури. Всі елементи в системі мають ієрархію і взаємний вплив, тобто створюють умови, при яких відтворюється система.

Системний підхід до розгляду соціально-економічних явищ і процесів активно розвивався в останній четверті двадцятого століття. Кожна система розглядалась у взаємозв'язку 3 іншими системами i керувалась системою більш високого порядку, яка, в свою чергу, управляла системами більш низького порядку. Так, Черняк В.К. дає таке поняття системи: «Система - это обладающая принципами устойчивости, т.е. организованностью, интегративными свойствами и относительной самостоятельностью, совокупность элементов и связей между ними» [1, с. 9].

Підприємство, як система виступає первинною господарською ланкою народного господарства держави як системи більш вищого порядку. На підприємстві безпосередньо створюються матеріальні блага для задоволення потреб населення та інших споживачів, а також реалізуються соціально-економічні інтереси виробничого колективу.

Як самостійний суб'єкт господарювання підприємство вирішує: що, де, коли, як і скільки виробляти, для якого споживача, за якою ціною реалізовувати продукцію 3 урахуванням витрат ресурсів та отримання відповідного прибутку, який забезпечить подальший соціально-економічний розвиток підприємства, його фінансову стабільність, стійкість і конкурентоспроможність.

Для розгляду підприємства як системи та його розвитку, характерні наступні принципи:

а) цілісність, яка характеризує якісно нові властивості організації, в якій відображається кумулятивний ефект системності;

б) структурованість, яка характеризує якісну упорядкованість і відносну стійкість між підрозділами та відділами підприємства, їх організацію у системі управління.

в) взаємодії, як форми взаємозв'язку між елементами структури системи (технологічні, організаційні, управлінські), без якої система не працює;

г) неперервність, як умова відтворення ресурсів i результатів діяльності та умовою розвитку підприємства на якісно новому рівні.

Погляд на розвиток підприємства як систему досліджується в роботі Ю.С.Погорелова. Він підкреслює, що розвиток підприємства «це неперервний процес зміни стану підприємства 3 новою якістю порівняно з попереднім станом, в результаті у підприємства як складної системи виникають, розвиваються та реалізуються нові можливості, нові властивості, якісні характерні риси...» [2], що приводить до нового рівня розвитку підприємства.

В результаті зміни рівня розвитку підприємства, пише В.М.Афанасьєв, досягається якісний або кількісний приріст корисного результату, процесу в порівнянні 3 попереднім рівнем або 3 рівнем інших підприємств [3, с.96]. Тобто процес розвитку підприємства передбачає перехід на новий якісний рівень функціонування для подальшого його розвитку. Такої ж думки щодо розвитку підприємства, як системи, дотримується О.В.Шубравська, яка вважає, що розвиток підприємства, це «процес переходу системи із одного стану до іншого, що супроводжується змінами їі якісних і кількісних характеристик» [4, с. 38].

Процес економічного розвитку підприємства тісно зв'язаний з економічним зростанням. Разом 3 тим, це - різні поняття, але взаємозв'язані.

Процес розвитку може бути без зростання підприємства, його розмірів, випуску продукції та ін. Процес розвитку передбачає, в першу чергу, якісні зміни на підприємстві, які засновані на результатах досягнень науково-технічного прогресу та науково-технічної революції, інноваційних процесів. Зростання підприємства співпадає з розвитком, коли він є прогресивним в разі, коли розвиток без зміни кількісних характеристик, і регресивним - в разі, коли розвиток відбувається при зменшенні кількісних характеристик, зростання, і розвиток відрізняються один від одного. Такий же висновок підтримує В.М.Кошельник, який пише, що розвиток передбачає нарощування якісних змін організації системи..., а зростання можливо при незмінних якісних характеристиках системи [5].

Розвиток - це історично обумовлений процес, якій безперервний, але форми його прояву на кожному етапі різні. Тобто, можна погодитись 3 характеристикою розвитку підприємства, наданих авторами Дакус А.В. та Сімченко Н.О., які характеризують розвиток підприємства як «незворотні, керовані, вимірювальні, цілеспрямовані, закономірні, кількісно-якісні та сутнісні зміни економічної системи в довгостроковому періоді, що відбуваються під впливом економічних суперечностей потреб та інтересів...» [6]. 
Для визначення напрямків розвитку підприємства і факторів, які будуть впливати на його розвиток, їх можна поділити на зовнішні в межах країни та внутрішні.

До цих факторів можна віднести: досить невизначену державну економічну політика; консервативну систему споживання м'ясопродуктів; обмежену систему споживання за рахунок низької купівельної спроможності населення; для проведення інноваційних задів необхідні додаткові кошти, яких у більшості підприємств бракує.

Виходячи 3 цього, можна визначити напрями подальшого розвитку підприємства, розробити стратегію його розвитку на перспективу.

Якісні зміни внутрішнього середовища підприємства, оновлення організації, соціально-економічного стану та інновацій процес об' єктивно необхідний. Проте для підприємств м'ясопереробної галузі інноваційні стратегії на сучасному етапі їх функціонування не дуже популярні, що обумовлено низкою факторів.

Питання оцінки рівня розвитку підприємства розглядаються різними авторами і під різним кутом дослідження. Існують різні підходи і різні системи показників, за допомогою яких здійснюється оцінка. Серед основних напрямків оцінка може здійснюватися: за життєвим часом підприємства; за стадіями розвитку підприємства; за розвитком факторів виробництва; за динамічним розвитком; за ступенем реалізації потенціалу підприємства та інш.

Також розглядаються питання оцінки розвитку за напрямками діяльності та організаційною структурою, такі як: науково-технічний розвиток, техніко-організаційний, соціальноекономічний, організаційно-управлінській, ступеню конкурентоспроможності та інш.

Так Г. Я. Белякова i О. Л. Демидова розглядають техніко-організаційний рівень розвитку підприємства через систему показників, які об'єднані в три блоки: показники рівня управління господарською діяльністю; показники рівня організації праці і виробництва i показники науково-технічного рівня виробництва. На підставі розрахованих коефіцієнтів за показниками кожного блоку будують матрицю погодження показників системи організаційнотехнічного рівня розвитку підприємства [7, c.111]. Але даний підхід відображає тільки внутрішній стан підприємства без зв'язку його 3 зовнішніми системами.

Лисенко Д.В. пропонує використовувати інтегральні показники оцінки організаційнотехнічного рівня за допомогою коефіцієнтів оцінки різних рівнів організації, техніки, управління [8, с.218-219].
Стадійний підхід до оцінки рівня розвитку підприємства пропонує Шестакова О.В., яка розглядає розвиток як тенденцію, порівнюючи фактичні показники розвитку з нормативними, в подальшому їх ранжуючи в системі оцінки рівня розвитку підприємства [9, с.201-202 ].

Ступень реалізації складових потенціалу підприємства для оцінки рівня його розвитку пропонують Осипов П.В., В.Ю Самуляк і Фешур В.В. [10].

Для оцінки рівня розвитку підприємства нами пропонується модель системного підходу до характеристики підприємства, яка складається 3 взаємозв'язаних трьох блоків: блоку постачання, блоку виробництва та блоку збуту, які характеризують вертикальну інтеграцію взаємозв'язків між ними.

Для кожного блоку використовуємо найбільш характерну для нього систему показників. Розглянувши різні підходи для оцінки розвитку підприємства, нами пропонується змоделювати власну комплексну оцінку рівня розвитку підприємства, як системи вертикально інтегрованого його організаційно-економічного рівня. Оцінка розвитку підприємства розглядається тільки в динаміці. В нашій моделі порівняння здійснюємо 3 попереднім роком, тобто темпи зростання розраховуються ланцюговим способом.

Розглянемо перший блок - «постачання». Основним завданням в системі постачання ресурсів $\epsilon$ взаємозв'язок $з$ галуззю тваринництва, виробниками якої можуть бути фермери, домашні господарства, великі спеціалізовані компанії та інші. Особливе значення на даному етапі має бути розвиток виробництва великої рогатої худоби (далі - ВРХ), обсяги якої щорічно зменшуються. Щоб забезпечити необхідну структуру виробництва, м'ясопереробні підприємства повинні використовувати імпортну м'ясну сировину. Тісний взаємозв'язок між розвитком тваринництва, його результатами діяльності та м'ясопереробними підприємствами розглядається в роботах Лагодієнка В.В. та Орел В.М. [11], а також автора Магденко С.O. [12, с. 34-35].

Другий блок - «виробництво» характеризує ступінь ефективності використання ресурсів, які надійшли від постачальників: якості ресурсів, їх кількості, технологій, що використовуються, методів організації виробництва і праці, системи управління. В попередніх наших дослідженнях ми розглядали окремо ефективність використання факторів виробництва [13, с.120].

Третій блок системи характеризується реалізацією виробленої продукції, ефективність якої залежить від організації системи збуту на підприємстві, розвиненості збутової мережі, місткістю ринку споживачів цієї продукції, купівельної 
спроможності споживачів i, в першу чергу, населення. В цьому блоку важливо визначити, наскільки задоволений споживчий попит в цілому і за структурою м'яса та м'ясопродуктів, що буде підгрунтям для визначення стратегії розвитку підприємства $[13$, с.120].

При побудові моделі комплексної оцінки рівня розвитку підприємства спочатку визначаються значення часткових показників кожного блоку (складової) по роках, потім визначаються їх щорічні темпи зростання (індекси - I), потім визначаються інтегральні показники постачання, виробництва та збуту (Тпост, Твир, Тзбут) і в кінці - інтегральний показник розвитку діяльності підприємства - Трозв.

Модель визначення рівня розвитку діяльності підприємства пропонується розраховувати через коефіцієнти - темпи зростання визначених показників і виглядає в загальному вигляді як середньогеометрична від добутку середньогеометричних значень показників, виражених в коефіцієнтах (індексів) кожного блоку:

$$
\begin{aligned}
& \text { Tрозв* }=\sqrt[3]{\text { Tпост } * \text { Твир } * \text { Тзбут }}, \\
& \text { *розроблено автором }
\end{aligned}
$$

де Тпост - темп зростання складової «постачання», коефіцієнт; Твир - темп зростання складової «виробництво», коефіцієнт; Тзбут темп зростання складової «збут», коефіцієнт; Трозв теж коефіцієнт.

При (нормальній) звичайній діяльності підприємства темпи зростання (коефіцієнти) знаходяться в межах $0,8-1,2$.

Якщо інтегральний коефіцієнт або якоїсь складової або ефективності діяльності в цілому менше 1, то можна говорити про погіршення ефективності діяльності підприємства; якщо коефіцієнт більше 1 - можна робити висновок про розвиток діяльності підприємства.

Також можна проаналізувати, які фактори i яким чином (позитивно або негативно) вплинули на розвиток підприємства або на його затримку.

Для кожної складової визначено основні показники, що можуть характеризувати ефективність діяльності певної складової.

Простота моделі полягає в тому, що ії можна розрахувати за допомогою показників, які $\epsilon$ в статистичних звітах в загальному доступі (Баланс ф. №1, Звіт про фінансові результати ф. №2 та ін.)

Так, для блоку «постачання» нами розглядаються такі показники, як коефіцієнт виконання договорів поставок м'яса, розмір кредиторської заборгованості, сума матеріальних витрат та коефіцієнт випередження матеріальних витрат перед кредиторською заборгованістю.

$$
\begin{aligned}
& \text { Tnост* }=\sqrt[4]{I K \partial о г * I K 3 * I M B * I K в u n_{-} \text {мв }} \\
& \text { * розроблено автором }
\end{aligned}
$$

де ІКдог - індекс коефіцієнтів виконання договорів постачання сировини; ІКЗ - індекс кредиторської заборгованості; IMB - індекс матеріальних витрат; ІКвип_мв - індекс випередження матеріальних витрат перед кредиторською заборгованістю.

Для блоку «виробництво» обрано такі показники, які б характеризували ефективність використання всіх елементів виробничого процесу - основних фондів, оборотних коштів та персоналу: фондовіддача, коефіцієнт оборотності матеріальних ресурсів або оборотних коштів (ми зупинилися на матеріальних ресурсах) та продуктивність праці.

$$
\begin{aligned}
& \text { Твир* }=\sqrt[3]{I \Phi в * I К о б ~ * ~ І П П ~} \\
& \text { *розроблено автором }
\end{aligned}
$$

де ІФв - індекс фондовіддачі; ІКоб - індекс коефіцієнта оборотності матеріальних ресурсів; ІПП - індекс продуктивності праці.

Для блоку «збут» обрано такі показники: частка надходження грошових коштів в загальній сумі реалізованої продукції, сума дебіторської заборгованості (ефективність платіжної дисципліни), сума реалізованої продукції, коефіцієнт випередження реалізованої продукції перед дебіторською заборгованістю.

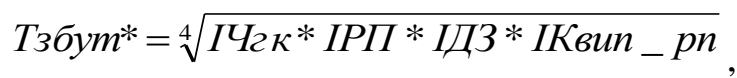

$$
\begin{aligned}
& \text { *розроблено автором }
\end{aligned}
$$

де ІЧгк - індекс частки грошових коштів в загальній сумі реалізованої продукції; IPП індекс реалізованої продукції; ІДЗ - індекс суми дебіторської заборгованості; ІКвип_рп - індекс коефіцієнта випередження реалізованої продукції перед дебіторською заборгованістю.

Розрахунок запропонованої моделі оцінки рівня розвитку підприємства розглянемо на прикладі ПрАТ «Комплекс Безлюдівський м'ясокомбінат» [14]. У таблиці 1 наведено результати розрахунків динаміки часткових показників та інтегральних показників за блоками та в цілому по підприємству.

За розрахунками інтегральних показників, наданих в таблиці 1, можна спостерігати, що найбільш активний розвиток на підприємстві спостерігається в 2014 році порівняно із 2013 роком. Зараз спостерігається незначний щорічний розвиток підприємства. 
Таблиця 1

Розрахунок темпів зростання інтегральних показників за блоками та загального інтегрального темпу зростання*

\begin{tabular}{|c|c|c|c|c|}
\hline \multirow{2}{*}{ Показники } & \multicolumn{4}{|c|}{ Роки } \\
\hline & $\begin{array}{l}2013 \text { p. до } \\
2012 \text { p. }\end{array}$ & $\begin{array}{c}2014 \text { р. до } \\
2013 \text { р. }\end{array}$ & $\begin{array}{c}2015 \mathrm{p} \text { до } \\
2014 \mathrm{p} .\end{array}$ & $\begin{array}{l}2016 \text { p. до } \\
2015 \text { p. }\end{array}$ \\
\hline \multicolumn{5}{|l|}{ блок «Постачання» } \\
\hline Індекс коефіцієнтів виконання договорів & 1,0103 & 1,0204 & 1,0000 & 1,0000 \\
\hline Індекс кредиторської заборгованості (К3) & 1,4843 & 1,7729 & 1,2078 & 1,3125 \\
\hline Індекс матеріальних витрат (MB) & 0,9080 & 1,7404 & 1,1736 & 0,9465 \\
\hline Індекс коефіцієнтів випередження МВ перед КЗ & 0,6118 & 0,9817 & 0,9717 & 0,7212 \\
\hline Інтегральний показник Тпост & 0,9553 & 1,3259 & 1,0833 & 0,9729 \\
\hline \multicolumn{5}{|l|}{ блок «Виробництво» } \\
\hline Індекс фондовіддачі & 0,6611 & 1,2809 & 1,0942 & 0,9406 \\
\hline Індекс коефіцієнтів оборотності матеріальних ресурсів & 0,9096 & 0,8957 & 1,0812 & 1,0564 \\
\hline Індекс продуктивність праці & 0,7543 & 1,2500 & 1,2572 & 0,9236 \\
\hline Інтегральний показник Твир & 0,7683 & 1,1281 & 1,1415 & 0,9718 \\
\hline \multicolumn{5}{|l|}{ блок «Збут» } \\
\hline $\begin{array}{l}\text { Індекс частки надходження грошових коштів в обсязі } \\
\text { реалізації }\end{array}$ & 1,2541 & 0,8259 & 0,7276 & 1,5690 \\
\hline Індекс реалізованої продукції (РП) & 0,8259 & 1,5607 & 1,2688 & 0,9999 \\
\hline Індекс дебіторської заборгованості (ДЗ) & 0,7756 & 1,5002 & 1,0631 & 1,1034 \\
\hline Індекс коефіцієнту випередження РП до ДЗ & 1,0649 & 1,0403 & 1,1936 & 0,9062 \\
\hline Інтегральний показник Тзбут & 0,9617 & 1,1909 & 1,0403 & 1,1191 \\
\hline Інтегральний показник Трозв & 0,8904 & 1,2122 & 1,0876 & 1,0190 \\
\hline
\end{tabular}

*Розраховано автором

Висновки та перспективи подальших досліджень. В результаті проведеної оцінки рівня розвитку ПрАТ «Комплекс Безлюдівський м'ясокомбінат» можна зробити висновок про його динамічний рівень розвитку, а також визначити фактори, які вплинули на кінцеві показники розвитку підприємства. По-перше, це зростання основних засобів при незмінному обсягу реалізації, що привело до зниження фондовіддачі; по-друге, це збільшення чисельності працівників при незмінному обсягу реалізації, що привело до зниження продуктивності праці; по-трете, зростання кредиторської заборгованості при зниженні суми матеріальних витрат. Таким чином, для прийняття управлінських рішень для подальшої стратегії розвитку підприємства пропонується раціональне використання ресурсів, покращення управління дебіторською та кредиторською заборгованістю, оптимізації наявності основних засобів.

В перспективі проведення подальших досліджень $€$ вивчення впливу кожного 3 факторів на інтегральну оцінку як за окремим блоком, так і інтегральної оцінки в цілому. Також планується спрогнозувати темпи розвитку підприємства через декілька років із застосуванням вбудованих функцій Excel.

\section{ПЕРЕЛІК ВИКОРИСТАНИХ ДЖЕРЕЛ}

1. Черняк В.К. Структура экономического развития / В.К. Черняк. - К.: Наукова думка. - 1981. -216 с.

2. Погорелов Ю.С. Категорія розвитку та ії експлейнарний базис /Ю.С.Погорелов. [Електронний ресурс]. Режим доступу:http://tppe.econom.univ.kiev.ua/data/2012_27_1/Zb27_1_04.pdf.

3. Афанасьев Н.В. Управление развитием предприятия: монография [Текст] / Н.В. Афанасьев, В.Д. Рогожин, В.И. Рудыка - Х.: ИД «ИНЖЭК», 2003. - 184 с.

4. Шубравська О.В. Сталий економічний розвиток. Поняття i напрямки дослідження/ О.В.Шубравська//Економіка України. - 2005 -№1. - С. 36 - 42

5. Кошельник В.Н. Развитие предприятия: экономическая сущность и видовая классификация /В.Н.Кошельник. [Електронний ресурс]. - Режим доступу: http://jurnal.org/articles/2014/ekon71.html

6. Дакус А.В., Сімченко Н.О. Економічний розвиток підприємства: сутність та визначення/ Дакус А. В., Сімченко Н. О. // Актуальні проблеми економіки та управління : збірник наукових праць [Електронний ресурс]. - Режим доступу: http://ela.kpi.ua/handle/123456789/12350

7. Белякова Г.Я, Демидова Е.А. Оценка технико-организационного уровня развития металлургического предприятия// Экономические науки -№7 (92) - 2012. - c.110-114

8. Комплексный экономический анализ хозяйственной деятельности: Учебник для вузов / Д.В. Лысенко. М.: ИНФРА-М, 2013. - 320 c 
9. Шестакова Е.В. Методические основы стадии развития предприятия как самоорганизующейся системы/Е.В. Шестакова //Вестник ОГУ. -№4(135). - 2014. - С. 198 - 206

10. Самуляк В.Ю., Фещур Р.В. Оцінювання рівня розвитку підприємств. Національний університет «Львівська політехніка», 2008. - С.627 - 636. [Режим доступу] http://vlp.com.ua/node/2875

11. Лагодієнко В.В., Орел В.М. Розвиток інноваційної діяльності підприємств м'ясопереробної галузі [Електронний ресурс]. - Режим доступу: http://dspace.nbuv.gov.ua/bitstream/handle/ 123456789/93222/55Lagodienko.pdf?sequence $=1$

12. Магденко С.О. Сучасний стан та тенденції стійкого розвитку харчової промисловості на прикладі м’ясопереробної галузі / С.О. Магденко //Економіка харчової промисловості, том 9, випуск 2/2017, с.33-38

13. Ощепков О.П., Магденко С.О. Оцінка динаміки розвитку підприємств м’ясопереробної галузі України. Статистична оцінка соціально-економічного розвитку: зб. Текстів доповідей за матеріалами:XVII Всеукраїнської наук.-практ. конф., 26 травня 2017р. - Хмельницький університет управління та права, 2017. c. 119-121.

14. Офіційний сайт Національної комісії з цінних паперів та фондового ринку [Електронний ресурс]. Режим доступу: https://smida.gov.ua/db/participant/22722461 (дата звернення 15.01.2018)

\section{REFERENCES}

1. Chernjak, V.K. (1981). Struktura jekonomicheskogo razvitija [Structure of economic development]. -Kyiv: Naukova dumka [in Russian].

2. Pogorelov, Iu.S. (2012). Kategoriia rozvitku ta iï ekspleinarnii bazis [Category of development and its explinational basis]. Retrieved from: http://tppe.econom.univ.kiev.ua/data/2012_27_1/Zb27_1_04.pdf [in Ukrainian]

3. Afanasev, N.V., \& Rogozhin, V.D., \& Rudyka, V.I. (2003). Upravlenie razvitiem predprijatija [Enterprise Development Management]/- Kharkiv: ID INZheK [in Russian].

4. Shubravs'ka, O.V. (2005). Stalyj ekonomichnyj rozvytok. Ponjattja i naprjamky doslidzhennja [Sustainable economic development. Concept and directions of research]. Ekonomika Ukrainy - Economy of Ukraine, 1, 36 - 42 [in Ukrainian]

5. Koshel'nik, V.N. (2014). Razvitie predpriyatiya: ekonomicheskaya sushchnost' $i$ vidovaya klassifikatsiya [Enterprise development: economic essence and class classification]. Retrieved from: http://jurnal.org/articles/2014/ekon71.html

6. Dakus, A.V. \& Simchenko, N.O. Ekonomichnyj rozvytok pidpryjemstva: sutnist' ta vyznachennja [Economic development of an enterprise: essence and definition]. Aktual'ni problemi ekonomiki ta upravlinnja - Actual problems of economics and menegement. Retrieved from: http:// ela.kpi.ua/handle/123456789/ 12350 [in Ukrainian].

7. Beljakova, G.Ja. \& Demidova, E.A. (2012). Otsenka tekhniko-organizatsionnogo urovnya razvitiya metallurgicheskogo predpriyatiya [Assessment of the technical and organizational level of development of the metallurgical enterprise]. Ekonomicheskie nauki - Economic sciences, 7 (92), 110-114 [in Russian]

8. Lysenko, D.V. (2013). Kompleksnyj jekonomicheskij analiz hozjajstvennoj dejatel'nosti [Complex economic analysis of economic activity].- Moscow: INFRA-M [in Russian]

9. Shestakova, E.V. (2014). Metodicheskie osnovy stadii razvitiya predpriyatiya kak samoorganizuyushcheisya sistemy [Methodical bases of the stage of development of the enterprise as a self-organizing system]. Vestnik OGU Vestnik of OSU, 4(135), 198 - 206 [in Russian]

10. Samuljak,V.Iu. \& Feshhur, R.V. (2008). Ocinjuvannja rivnja rozvytku pidpryjemstv [Assessment of enterprise development level]. - Lviv: Nacional'nij universitet «L'vivs'ka politehnika». Retrieved from: http://vlp.com.ua/node/2875 [in Ukrainian].

11. Lagodijenko,V.V. \& Orel, V.M. Rozvytok innovacijnoi' dijal'nosti pidpryjemstv m'jasopererobnoi' galuzi [Development of innovative activity of enterprises of the meat processing industry] Retrieved from: http://dspace.nbuv.gov.ua/bitstream/ handle/ 123456789/93222 /55-Lagodienko.pdf?sequence=1 [in Ukrainian].

12. Magdenko, S.O. (2017). Suchasnyj stan ta tendencii' stijkogo rozvytku harchovoi' promyslovosti na prykladi m'jasopererobnoi' galuzi [The current state and trends of sustainable development of the food industry on the example of the meat processing industry]. Ekonomika harchovö̈ promislovosti - Food Industry Economics, 2/2017 (9), 33 -38 [in Ukrainian].

13. Oshhepkov, O.P. \& Magdenko, S.O. (2017). Ocinka dynamiky rozvytku pidpryjemstv m'jasopererobnoi' galuzi Ukrai'ny [Assessment of the dynamics of development of enterprises of the meat processing industry of Ukraine]. Proceedings from XVII Vseukraïnskoï naukovo-praktychnoi konferencii «Statistichna ocinka social'no-ekonomichnogo rozvitku: zbirnyk tekstiv dopovidei» - The XVII All-Ukrainian Scientific and Practical Conference «Statistical assessment of socio-economic development». (pp.119-121). Hmel'nyc'kyj: Hmel'nic'kij universitet upravlinnja ta prava [in Ukrainian].

14. Ofitsiinyi sait Nacionalnoi komisii z cinnyh paperiv ta fondovogo rynku [The official website of the National Commission on Securities and Stock Market]. smida.gov.ua. Retrieved from: http://smida.gov.ua/db/participant/22722461 [in Ukrainian]. 